\title{
Trademark evaluation of the selected company in the aspect of globalization
}

\author{
Anna Kubjatkova ${ }^{1, *}, J_{u r a j}$ Kolenč́́k ${ }^{2}$ \\ ${ }^{1}$ University of Zilina, Faculty of Operation and Economics of Transport and Communications, \\ Department of Economics, Univerzitna 1, 01026 Zilina, Slovak republic \\ ${ }^{2}$ University of Zilina, Faculty of Operation and Economics of Transport and Communications, \\ Department of Economics, Univerzitna 1, 01026 Zilina, Slovak republic
}

\begin{abstract}
The awareness of intangible assets is growing more and more today. Compared to the past, we are much more aware of the existence of a certain intangible substance which, together with the material substance, constitutes the value of society. Determining the value of an enterprise's intangible assets on a global scale is becoming increasingly important as the value of an enterprise is not made up of only its tangible assets but its intangible side. An obvious part of intangible assets is also a trademark. The trademark is now much more important for companies, also due to globalization. It is an essential part of the company's intangible assets, which is very often underestimated and therefore it is necessary to choose the right procedure for determining the value of all its components. As a result of globalization and comprehensive marketing strategies are trademark valuation methods gradually beginning to unite around the world. The main aim of this work was to choose a suitable valuation method of a trademark and to calculate its value in a selected company. We chose this aim because evaluation of the trademark appraisal is very often a difficult topic for businesses and the general public.
\end{abstract}

\section{Introduction}

Globalization of the economy and balancing the boundaries of business activities require not only comparability of corporate marketing strategies, but also methods of valuing the value of intangible assets. [1]

To constantly satisfy their customers, companies need to do market research. Obtaining information from customers is therefore a very important business issue. Detecting customer requirements often affects the presentation of the company, but even the structure of the company's assets. [2]

If companies are able to meet the needs and requirements of their customers, then their financial profit is also increasing. However, the company must have a constant overview of the current customer requirements, otherwise the company could fail and could run into financial problems. This could eventually lead to debt and eventual inability to repay these debts. [3]

\footnotetext{
*Corresponding author: anna.kubjatkova@ fpedas.uniza.sk
} 
The performance of companies continues to grow if they are constantly striving to meet the needs of their customers. The actual measurement of the performance of such companies is based primarily on the existence of an economic profit which depends on the customer satisfaction itself. [4]

Not only the performance of the company as a whole is an integral part of the positive result of the company. A special place in the performance of the company has its financial performance and its overall scope of application. The financial performance of the company is closely linked to the ability to meet the customer's expectations and adapt not only the product and services, but also how to protect these products from misuse by other companies. [5]

Today, companies need to adapt to market conditions as much as possible. Traditional economic activity is often not sufficient to create certain economic benefits on the market. In this respect, it is recommended to replace this traditional economic activity with more modern and cutting-edge technologies. These technologies and procedures are often part of the company's intangible assets, so it is increasingly emphasized by the companies themselves. [6]

In the 21 st century, physical assets such as land and machinery are no longer the most valuable strategic resources for business, but rather intangible assets such as knowledge, patents and intellectual property rights. Thus, the intangible assets of the company come to the forefront, which by using it can bring the company advantages in the fight for customers. [7]

Every company, in economy and, in a sustainability-aware era, is "doomed" to deal with a mass of strategic assets, in order to achieve a sustainable competitive advantage. These are not intangible assets but also tangible assets. [8]

Recently, intangible assets have taken a special place in the corporate asset structure of a modern company. These resources include general knowledge, company software, market access and participation, company reputation, valuable rights, organizational culture and qualitative characteristics of human resources. Most of the company's intangible assets create so-called. intellectual capital, which is important for competition. [9]

Changing the overall economy, developing information technology, marketing strategies and globalization have contributed to increasing attention to capital, where the substance is no longer the most important measure. Intellectual capital includes both measurable and non-measurable intangible assets of a company that are considered to be a source of competitive advantage and an integral part of corporate assets. [10]

Intangible assets have a very important role to play in the process of building the value of society. These assets include knowledge, market access and participation, corporate reputation, organizational culture, and qualitative characteristics of human resources. Intangible assets may include software solutions, goodwill or patents and trademarks as part of valuable rights and various other components of an intangible asset. However, neither accounting theory or world trade practices don't present a clear and precise definition of intangible assets, or they ways of classifying and measuring them too. It is precisely because of the inconsistency of the regulations and procedures that the perception of intangible assets is often distorted not only by the enterprises themselves but also by their surroundings. [11]

The most valued intangible assets of an enterprise are software, trademark and patent. Patent protection standards were among the first laws to protect at all. Patent pools are commonly used to prosecute technology licensing. [12]

Companies spend a great deal of money on the marketing and advertising of their products or services under their brand, so it is essential to protect them from unauthorized use. A trademark represents the prestige of a particular company and also brings higher 
returns and saves costs. This impact on the business can be quantified as a trade mark value. [13]

Evaluation of the trademark is a long process and should be carried out by an appropriate expert with expert in the field. It is therefore necessary to treat this work as a design, not as a binding procedure for evaluating a company's trademark.

The value of a brand or trademark is perceived by customers from different perspectives. Companies should analyze the perception of price and brand value by their customers in order to be able to continually adapt them to current market requirements. [14]

There are several ways to define a trademark globally. The name of the trademark itself is not uniform in the legal system of individual countries. The United States uses the trademark and the United Kingdom uses the trade mark. In the European Union and its legal system, as well as in the World Trade Organization and in the World Intellectual Property Organization, use both terms. [15]

However, it should be clarified that the trade mark designation TM itself is a designation for an unprotected trade mark, the symbol designating an unregistered trade mark. On the contrary, it is a protected trade mark in the case of the sign ${ }^{\circledR}$. The ${ }^{\circledR}$ mark alone means that the trademark is registered. [16]

A trademark is any sign which can be represented graphically and which consists primarily of words including personal names, numbers, letters, drawings, the packaging of the goods or their shape, if such a marking is capable distinguish the goods and services of one person from another.

This work consists of four main parts. In the first part of this work we dealt with the introduction to the issue of perception of intangible assets by companies themselves, since the trademark is a part of intangible assets. The second part deals with the evaluation methods of the trademark used for the purposes of this work. At the same time, in this section we choose the appropriate way to rate a trademark. In the third part we present the actual calculation of the value of the trademark on the basis of previous knowledge. The last part of the work is devoted to the evaluation of the results and other possible suggestions and considerations concerning the company's trademark.

For this work we chose Kysucke pekarne, a. s., which is the best known and also the largest bakery company in the north of the Slovak Republic. The company has been using the Vilija trademark since 1996, which covers the entire production of the company. This mark has not yet been rated, so the company does not know its fair value. The company has its trademark protected only within this state through the Industrial Property Office of the Slovak Republic, ie the trademark is not protected abroad in any way.

\section{Methodology}

\subsection{Trademark evaluating methods}

There are various methods of trademark evaluation. We use the comparative method to identify the trademark market in question and obtain all information about transactions of this type. This is followed by an analysis of the information and a check on the relevance and actuality of the information. Subsequently, comparable marks are selected and each is analyzed and finally compared to the mark being evaluated.

The cost method is mainly used if the trademark is not used for a long time. However, this method does not take into account the future benefits that would result from the use of the trademark and is therefore too static.

Yield methods are most often used to evaluate a trademark because they are dynamic and take into account the future benefits of the trademark. The most used yield method of valuation is licensing analogue method. It assumes that the value of the trademark in 
question is the same as the price that would have been paid for its consent to use if it were not owned by the company itself.

It is necessary to choose the appropriate method of valuation of the trademark of Kysucke pekarne, a. s. It is not appropriate to use the comparative method in the Slovak Republic because there is not enough database of trademarks in the country which we could compare the Vilija trademark with. We will also not use the cost valuation method because it only takes into account the cost of acquiring and maintaining the trademark. Applying this method is not convenient because it does not take into account the sale associated with the use of this trademark, so we will not use this method to evaluate it. Therefore, the most appropriate method of evaluating a trademark is the yield method, from which we choose the method of licensing analogy which takes into account the future benefits that will result from the use of this trademark. The method was also chosen because it is the most commonly used globally to determine the value of a company's trademark. The annual value of a trademark may be determined by the following method:

$$
T V=\frac{P R+L F+E C * P A}{D C}
$$

TV - trademark value for a particular year [Eur]

PR - production range for a year - predicted sale [Eur]

LF - license fee [Eur]

EC - evaluation coefficient [\%/100]

PA - the proportion of intangible assets protected by the trademark [\%/100]

DC - discount rate coefficient - commonly known as the capitalization rate coefficient, and is used to convert license fee to net present value [\%]

In order to use this method, it is necessary to determine the annual production range according to the information on sales from previous years, which we used from the annual report of the company. Sale based on historical data is determined by sale for the past 9 years [17]:

Table 1. Historical sales for 2009 - 2017

\begin{tabular}{|c|c|}
\hline Year & Sales [Eur] \\
\hline 2009 & 5533771 \\
\hline 2010 & 5731958 \\
\hline 2011 & 5616856 \\
\hline 2012 & 5553674 \\
\hline 2013 & 5869425 \\
\hline 2014 & 6338514 \\
\hline 2015 & 6375819 \\
\hline 2016 & 6471507 \\
\hline 2017 & 5871740 \\
\hline
\end{tabular}

The company provided us with predicted sales for the next 2 years: 
Table 2. Predicted sales for 2018 and 2019

\begin{tabular}{|c|c|}
\hline Year & Sales [Eur] \\
\hline 2018 & 6796033 \\
\hline 2019 & 7384656 \\
\hline
\end{tabular}

We can see from the table that sales increased over the past 8 years, except for 2011, 2012 and 2017. Based on historical and predicted sale development, we determined that future long-term sale growth is $2.85 \%$. Then we used this percentage of growth for the next 6 years. In 2026, the company will reconsider the renewal of the trademark in question, so we have not taken this year into consideration in terms of caution.

Table 3. Predicted sale growth for 2018 - 2025

\begin{tabular}{|c|c|}
\hline Year & Sales [Eur] \\
\hline 2020 & 7615796 \\
\hline 2021 & 7854170 \\
\hline 2022 & 8100006 \\
\hline 2023 & 8353536 \\
\hline 2024 & 8615002 \\
\hline 2025 & 8884651 \\
\hline
\end{tabular}

To evaluate the trademark Vilija for 2017 using the license analogue method, we will use the formula (1), which contains:

- annual production scale - future sales,

- license fee - based on the fact that it is the food industry, trademarks have a higher value of license fee as in the engineering industry. The essence of production is a staple food of normal consumption, and the constant demand for this staple item reduces the value of the license fee. Taking into account all other factors affecting the amount of the license fee, such as the length of trademark protection and use of the trademark (more than 20 years), the location of production, the size of the business and its market position, the use associated with the company logo, we determine the amount of the license fee. We set it as $1 \%$ of revenue from sales of products and services,

- valuation coefficient - we estimate the coefficient as $100 \%$ due to industry and caution,

- the proportion of intangible assets protected by the trademark - Vilija trademark is the only trademark of the company and protects $100 \%$ of the company's production,

- discount rate coefficient - we determine it using the formula:

$$
W A C C=c_{E} * \frac{E E}{C}+c_{L} *(1-t) * \frac{E L}{C}
$$

\footnotetext{
WACC - weighted average cost of capital [Eur]

$c_{E} \quad-$ rate of equity costs $[\%]$

$c_{L} \quad-$ rate of liability costs [\%]

$\mathrm{EE} \quad-$ equity of the enterprise [Eur]
} 
EL - interest-bearing liability of the enterprise [Eur]

$\mathrm{t} \quad-$ income tax [\%]

C - total enterprise capital [Eur]. (Decree No. 492/2004 Coll.)

In calculating the weighted average cost of capital, we must first determine the cost of equity and liability capital. The cost of equity can be calculated using the Capital Asset Pricing Model (CAPM) or using the modular method. To calculate the cost of equity, we chose the CAPM model as the most commonly used model to estimate the cost at present. The basic shape of this model is expressed as:

$$
r_{V K}=r_{f}+\beta_{i} *\left(r_{m}-r_{f}\right)
$$

$$
\begin{array}{ll}
r_{E C} & \text { - equity costs [\%] } \\
r_{f} & \text { - risk - free interest rate [\%] } \\
\beta_{i} & \text { - beta [coef] } \\
\left(r_{m}-r_{f}\right) & \text { - market risk premium [\%]. (Jakubec, Kardos, 2016) }
\end{array}
$$

The risk-free interest rate is known as the average yield of government bonds issued in 2017. The beta coefficient represents the systematic market risk that an investor takes when investing in a risky asset, and can be found on the Damodaran website. The market risk premium is also found on the Damodaran website, expressing a premium for the investor for investing capital in a risky asset.

Table 4. Calculation of the cost of equity

\begin{tabular}{|c|c|c|c|}
\hline $\begin{array}{c}\text { Risk - free interest } \\
\text { rate [\%] }\end{array}$ & Beta [coef] & $\begin{array}{c}\text { Market risk premium } \\
{[\%]}\end{array}$ & Equity costs [\%] \\
\hline 1,94 & 1,30 & 6,90 & 10,91 \\
\hline
\end{tabular}

The cost of liability capital can be calculated more easily than the cost of equity. Several methods can also be used, but we will use data from Damodaran, where the cost of capital is $4.43 \%$.

The total cost of capital can therefore be calculated according to formula (2) at 5.69\%.

\section{Results}

In the following table, we calculated the trademark value based on the values we found.

Table 5. Calculation of the general value of a trade mark

\begin{tabular}{|c|c|c|c|c|c|c|}
\hline Year & PR [Eur] & LF [\%/100] & $\begin{array}{c}\text { EC } \\
{[\% / 100]}\end{array}$ & $\begin{array}{c}\text { PA } \\
{[\% / 100]}\end{array}$ & $\begin{array}{c}\text { DC } \\
{[\% / 100]}\end{array}$ & $\begin{array}{c}\text { TV } \\
{[\text { Eur] }}\end{array}$ \\
\hline 2018 & 6796033 & 0,01 & 1 & 1 & 1,057 & 64295,49 \\
\hline 2019 & 7384656 & 0,01 & 1 & 1 & 1,117 & 66111,51 \\
\hline 2020 & 7615796 & 0,01 & 1 & 1 & 1,181 & 64486,00 \\
\hline 2021 & 7854170 & 0,01 & 1 & 1 & 1,248 & 62934,05 \\
\hline 2022 & 8100006 & 0,01 & 1 & 1 & 1,319 & 61410,21 \\
\hline 2023 & 8353536 & 0,01 & 1 & 1 & 1,395 & 59881,98 \\
\hline 2024 & 8615002 & 0,01 & 1 & 1 & 1,474 & 58446,42 \\
\hline 2025 & 8884651 & 0,01 & 1 & 1 & 1,558 & 57026,00 \\
\hline$\sum$ & - & - & - & - & - & $\mathbf{4 9 4} \mathbf{5 9 1 , 6 6}$ \\
\hline
\end{tabular}


Based on the calculation, we evaluated the trademark of Kysucke pekarne, a. s., to the value of $494591,66 €$.

The company's intangible assets included only software, so its value according to the annual report available at www.finstat.sk was 54,121 $€$. The value of intangible assets after evaluation of the trademark is approximately 548,713 €. As of 31 December 2017, the company's assets amounted to 8,080,112 $€$ according to the company's annual report. The value of intangible fixed assets was lower, according to the original annual report, due to the fact that we included in the property structure a trademark of a company that was not in company's original property structure, because trademark was not quantified before. The amount of the company's assets after the trademark evaluation has been included is $8,574,704 €$.

\section{Conclusions}

It is clear from the calculation that company should consider evaluating its trademark as it has a great influence on the value of its total assets. The company should also consider the valuation of other components of its intangible assets as recipes and production processes. Being a bakery business, its secret practices and recipes are key to its market position.

This paper is an output of scientific project VEGA no. 1/0718/18: The impact of psychographic aspects of pricing on the marketing strategy of companies across products and markets.

\section{References}

1 G. Dlaskova, E. Cipovova, Valuation of intangible assets according to Czech accounting standards and IFRS in the context of explanatory power of financial statements. Marketing and Management of Innovations, 59-67 (2018)

2 A. Krizanova, L. Gajanova, M. Nadanyiova, Design of a CRM Level and Performance Measurement Model. Sustainability, 10 (2018)

3 K. Valaskova, T. Kliestik, M. Kovacova, Management of financial risks in Slovak enterprises using regression analysis. Oeconomia Copernicana, 9, 100-121 (2018)

4 J. Salaga, V. Bartosova, E. Kicova, Economic Value Added as a measurement tool of financial performance, Proceedings of 4th World Conference on Business. Economics and Management (WCBEM), 484-489 (2015)

5 C. Fogarassy, E. Neubauer, H. Mansur, A. Tangl, J. Olah, J. Popp, The main transition management issues and the effects of environmental accounting on financial performance- with focus on cement industry. Administratie si Management Public, 31, 52-66 (2018)

6 G. H. Popescu, "Participation in the Sharing Economy: Labor, Exchange, and Consumption. An Empirical Analysis". Journal of Self-Governance and Management Economics 6, 122-127 (2018)

7 A. Nunes, J. Garcia, J. Lopes, V. Zefirov, Intangible assets - influence on the „return on equity “, 5668 (2018)

8 FM Battagello, L. Cricelli, M. Grimaldi, Prioritization of Strategic Intangible Assets in Make/Buy Decisions. Sustainability, 11 (2019)

9 J. H. Rooksby, C. S. Collins, Trademark trends and brand activity in higher education. Review of Higher Education, 40, 33-61 (2016) 
10 S. Mrazkova, Proceedings Intangible Assets and Firm Performance: Evidence from Western and Northern Europe. 10th European Conference on Intangibles and Intellectual Capital, 193-201 (2019)

11 T. Maszczak, Company in a Global Environment and Intangible Assets. Proceedings of 18th Annual Conference on Finance and Accounting, 301-309 (2018)

12 M. Reisinger, E. Tarantino, Patent pools, vertical integration, and downstream competition. Rand Journal of Economics, 50, 1, 168-200 (2019)

13 E. Hyranek, I. Durinova, Methods of trademark evaluation. Proceedings of International Scientific Conference on Marketing Identity 2016: Brands We Love, 104113 (2016)

14 A. Krizanova, J. Majerova, The proposal of activities of pricing policy in the process of building and managing brand value in Slovak Republic. Proceedings of International Conference on Information, Business and Education Technology (ICIBET), 416-419 (2013)

15 B. Beebe, JC. Fromer, Are we running out of trademarks? An empirical study of trademark depletion and congestion. Harvard Law Review, 131, 945-1045 (2018)

16 G. Thoma, The valuation of patent-trademark pairing as IP strategy: evidence from the USPTO. Industry and innovation (2019)

17 Annual report of the company Kysucke pekarne, a. s. for 2017, Available on the internet: http://www.registeruz.sk/cruz-public/domain/accountingentity/show/156541.

18 K. Valaskova, V. Bartosova, P. Kubala, Behavioural Aspects of the Financial Decision-Making. Organizacija, 52, 22-31 (2019) 